\title{
EXAMINING THE IMPACT OF EXTERNAL INFLUENCES ON POLICE USE OF DEADLY FORCE OVER TIME
}

\author{
MICHAEL D. WHITE \\ University of North Florida
}

Prior deadly force research has sought to identify appropriate mechanisms that can effectively control police officers' decisions to use deadly force. However, the relative impact of external discretion control policies on police shooting behavior remains largely unknown. Using data from Philadelphia for a period of more than two decades, this article employs interrupted timeseries analysis (ARIMA) to examine the impact of legislation and judicial intervention on use of deadly force by Philadelphia police officers. The article also considers the impact of larger, community-level characteristics on levels of deadly force. Findings produced modest support for the potential effect of external discretion control policies and community-level factors on police shooting behavior but generally suggest that dynamic changes in the internal working environment can outweigh the influence of the external mechanisms.

Keywords: police use of force, deadly force, influences on deadly force, time-series analysis

Over the past 40 years, much research has focused on identifying the primary determinants of police shooting behavior. Three sets of potentially influential variables emerge from prior research: situational, organizational, and environmental. Environmental variables are outside the police organization and include factors such as crime rates and degree of danger to the police. Organizational factors are within the police organization and include administrative policy, informal peer group norms, policies and philosophies of the chief, and philosophy and structure of the department. Situational variables refer to factors specific to each police-citizen encounter, such as citizens' demeanor, number of suspects present, and the presence of a weapon. This article considers the impact of environmental factors on police shooting behavior in Philadelphia from 1970 to 1992.

Fyfe (1987) argued that environmental, organizational, and situational variables comprise the external and internal police working environments. The external environment includes factors outside the police organization, such as crime rates and degree of danger to the police, as well as situational

EVALUATION REVIEW, Vol. 27 No. 1, February 2003 50-78 DOI: $10.1177 / 0193841 \mathrm{X} 02239018$

(C) 2003 Sage Publications 
variables such as citizens' demeanor or the presence of a weapon (Fyfe 1987). The internal working environment refers to factors within the police organization but is best described as the degree of license given to police officers to use deadly force (via administrative policy, informal peer group norms, policies and philosophies of the chief, etc.). White (2001) modified Fyfe's work by isolating the situation as a distinct category of influences that play a critical mediating role in the decision-making process, affecting how the officer perceives the situation and determines the appropriate response to the suspect's actions. White also found that the relative importance of internal and external working environments and situational variables varies based on the nature of the shooting (e.g., whether the assailant is armed, physically assaultive or nonassaultive). ${ }^{1}$

Prior deadly force research suggests that the internal police working environment, particularly administrative policy, is an effective control of police shooting behavior if properly enforced (Fyfe 1979, 1988; Gain 1971; Geller and Scott 1992; White 2001). However, evidence of the impact of external influences on deadly force use is inconsistent. This article examines the impact of external influences on police shooting behavior from a different perspective using interrupted time-series analysis (ARIMA) and over two decades of police shooting data from Philadelphia (1970-1992). Four direct, external efforts to control deadly force discretion are examined: the June 1973 change in Pennsylvania state law governing justifiable homicide, the March 1973 issuance of a federal district court injunction (Rizzo v. Goode, 423 U.S. 362 [1976]; also 357 F. Supp. 1289; 506 F. 2d 542, 548 [1974]), the January 1976 U.S. Supreme Court ruling overturning that injunction, and Tennessee v. Garner (471 U.S. 1 [1985]), in which the U.S. Supreme Court established a national mandatory minimum requirement for use of deadly force. The article also considers the influence of several external communitylevel characteristics on deadly force levels, including population, number of sworn police, number of felony arrests, and number of homicides.

This article seeks to improve our understanding of the role and potential influence of external environmental factors on police shooting behavior. Examination of the impact of different types of influences on deadly force is important because it enhances our knowledge of how police shooting discretion operates. This knowledge not only provides evidence of the nature of deadly force use and the influence of police working environments, it also highlights the effectiveness of particular discretion control measures, both internal and external. Investigation of the impact of external discretion controls is particularly important given the traditional difficulties police have had policing themselves, especially with regard to use of force. 


\section{PRIOR RESEARCH ON ENVIRONMENTAL DETERMINANTS OF DEADLY FORCE}

Environmental determinants of deadly force use can be separated into two basic categories: community-level characteristics that indirectly affect police shooting behavior, such as the violent crime arrest rate, public homicide rate, and population level; and direct, external efforts to control deadly force discretion (e.g., discretion control policies such as court rulings and state laws). Prior deadly force research has studied the impact of both types of external influences on police shooting behavior.

\section{COMMUNITY CHARACTERISTICS}

Potentially violent police-citizen encounters typically occur in the community in which both participants live and/or work, and characteristics of that environment inevitably affect perceptions and behavior during the encounter. Kania and Mackey (1977) concluded that there is a significant relationship between police violence and police exposure to violent crime. ${ }^{2}$ Fyfe's (1980a) analysis of reported New York City police shootings from 1971 to 1975 showed that the police shooting rate was positively correlated with the violent crime arrest rate and the public homicide rate and that these associations were highest for shootings involving on-duty officers and lowest for shootings involving off-duty officers.

Also, there were high correlations between police shootings and threats to police and general public safety (Fyfe 1980a). In his analysis of Memphis shootings from 1969 to 1976, Fyfe (1982) concluded, "Police shootings are a consequence of violence in the community and the number of times members of various population subgroups expose themselves to the danger of being shot at by police" (p. 721).

Similarly, in their study of Chicago police from 1974 to 1980 , Geller and Karales (1981) found a strong positive association between police shootings and arrests for forcible felonies. In Alpert's (1989) analysis of police shootings in Miami from 1980 to 1986, he concluded that a community's culture of violence helps to explain variations in shooting rates across jurisdictions.

Liska and Yu (1992) also found a relationship between levels of community violence and levels of deadly force. Matulia (1985) examined the 57 largest U.S. cities and found positive correlations between use of deadly force by police and several measures of community violence, such as homicides, Uniform Crime Reports crimes, robberies, police officers murdered, and justifiable homicides by private citizens. Matulia concluded that police 
shooting rates were affected more by the level of violence in the community than any other factor, including organizational policy.

Alternatively, other researchers have posited a "conflict model," suggesting that police are more likely to use deadly force against "persons who live outside the American mainstream, particularly members of minorities" (Sorenson, Marquart, and Brock 1993, 417). Jacobs and Britt (1979) applied conflict theory to the use of deadly force and found support for the hypothesis that police are most likely to use deadly force when economic inequality and conflict are greatest. Sorenson, Marquart, and Brock (1993) examined both the "conflict" and "community violence" hypotheses and found a strong relationship between levels of economic inequality (and proportion of minorities) and deadly force incidents. Sorenson, Marquart, and Brock found a relationship between violent crime rates and use of deadly force but concluded that violent crime often acts as an intervening variable for other social variables: "Our analysis makes clear that economic inequality and the proportion of minorities in the population must be included in any future studies which attempt to explain the rate of police-caused homicide at the macro level" (p. 439).

\section{EXTERNAL DISCRETION CONTROL POLICIES}

In addition to aggregate-level community characteristics, external environmental influences on deadly force decision making can be much more direct or intentional. State statutes regarding justifiable homicide can limit police use of deadly force. According to Fyfe (1988), these discretion controls have several weaknesses. "First, even the most restrictive state laws permit police to use their weapons in an extremely broad range of situations" (p. 169). Also, the law is too vague regarding appropriate and acceptable behavior by police. Skolnick and Fyfe (1993) argued that "the criminal law remains so broad and presents so many enforcement problems that it cannot serve meaningfully as the parameters for any professional's discretion" (pp. 19798). Waegel's (1984) analysis of 459 police shootings in Philadelphia from 1970 to 1978 showed that, despite a major change in the Pennsylvania statute governing use of deadly force in 1973 (prohibiting shots to apprehend nonviolent felony suspects), $20 \%$ of the shootings violated legal standards. ${ }^{3}$

Judicial intervention can also serve as a discretion control for police field behavior, including use of deadly force. In 1985, the U.S. Supreme Court established a national mandatory minimum requirement for use of deadly force in Tennessee v. Garner. The Court ruled that deadly force is a constitutional means of effecting an arrest only when a "suspect threatens the officer 
with a weapon or there is probable cause to believe that he has committed a crime involving the infliction or threatened infliction of serious physical harm" (p. 4). Tennenbaum (1994) examined the effects of the Garner decision on use of deadly force nationwide and concluded that it reduced the number of police killings by 60 homicides a year (a 16\% decrease).

In City of Los Angeles v. Lyons (461 U.S. 95, 98 [1983]), Adolph Lyons challenged the Los Angeles Police Department's use of the carotid control hold technique for subduing citizens in non-life-threatening situations. Although the Supreme Court dismissed the injunction sought by Lyons, the Los Angeles Police Department subsequently redefined the carotid control hold as a use of deadly force rather than a pain compliance hold (Skolnick and Fyfe 1993).

\section{PHILADELPHIA'S EXPERIENCE WITH EXTERNAL DISCRETION CONTROL POLICIES}

This study focuses specifically on the city of Philadelphia and its police department, the shooting behavior of its officers, and its experience with external environmental influences on deadly force. Particularly during the 1970s, the Philadelphia Police Department (PPD) experienced a number of direct efforts to affect levels of deadly force. These external efforts, including a change in Pennsylvania state law and court rulings arising from the Rizzo v. Goode case, represent the focus of this research. The research also examines the impact of the Tennessee v. Garner case, which set minimum standards for all American police departments, including Philadelphia.

\section{CHANGE IN PENNSYLVANIA STATE LAW (JUNE 1973)}

Before 1973, Pennsylvania law governing justifiable homicide adhered to the "fleeing felon" rule. The fleeing felon rule, which dates back to the Middle Ages, allowed police officers to use whatever force necessary, including deadly force, to effect an arrest. However, as time passed, the Supreme Court passed due-process measures that guaranteed the rights of the accused, and law enforcement became much more sophisticated. Consequently, in the view of many, the fleeing felon rule became outdated and barbaric (American Law Institute 1931). The Pennsylvania state legislature responded in 1973 by modifying its statute governing justifiable homicide. Essentially, Pennsylvania abandoned the fleeing felon rule for a much more restrictive standard. More specifically, the new statute said that a law enforcement officer 


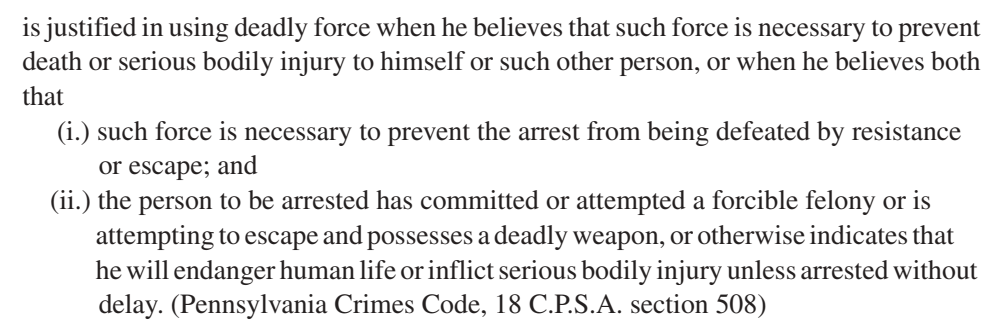

This change in law represented an intentional, focused effort by the Pennsylvania legislature to control police officers' use of deadly force (specifically, Philadelphia police officers), and this research examines the impact of the law on deadly force levels in Philadelphia.

\section{RIZZO v. GOODE}

A few years before the action taken by the Pennsylvania legislature, several individuals and public interest groups sought to initiate federal judicial intervention to affect use of force among Philadelphia police officers. In 1970, petitioners filed two separate and very important complaints against the mayor of Philadelphia, the police commissioner, and various other individuals. Goode (brother of Wilson Goode, the future mayor) and two other individuals filed the first action in February 1970 (Rizzo v. Goode). The second complaint, filed several months later in September, was brought by 21 individuals and four organizations, including the Council of Organizations on Philadelphia Police Accountability and Responsibility (COPPAR), the Southern Christian Leadership Conference, the Black Panther Party, and the Young Lords Party (COPPAR v. Rizzo, 357 F. Supp. 1289, 1321 [1973]). Both cases proceeded as class actions, with the respondents in both parties representing all Philadelphia residents, particularly all Black residents.

The central thrust of respondents' efforts in the two trials was to lay a foundation for equitable intervention, in one degree or another, because of an assertedly pervasive pattern of illegal and unconstitutional mistreatment by police officers. This mistreatment was said to have been directed against minority citizens in particular and against all Philadelphia residents in general. (Rizzo v. Goode, 423 U.S. at 366-67 [1976])

In the Goode case, petitioners presented eight examples of officer abuse to the district court. Two officers in the Department's Highway Patrol Unit were involved in all eight incidents (357 F. Supp. 1294-1316). Petitioners in the COPPAR case presented 28 cases of mistreatment. The district court ruled on March 14, 1973, that the evidence presented was not strong enough to 
support the respondents' claims that the named petitioners violated their constitutional rights, nor did it direct the PPD to change its deadly force policy (357 F. Supp. 1289). However, the court did find that the police department exhibited "a tendency to discourage the filing of civilian complaints and to minimize the consequences of police misconduct" (Rizzo v. Goode, 423 U.S. 362, 368-69 [1976]; also 357 F. Supp. 1289). The court found that only a small percentage of officers were responsible for the mistreatment but that the frequency of abuse prevented the occurrences from being dismissed "as rare, isolated incidents" (COPPAR v. Rizzo, 357 F. Supp. at 1319 [1973]). In addition, the district court ordered the police department to develop and submit to the court a plan for recording and responding to civilian complaints (357 F. Supp. 1319). ${ }^{4}$

Finally, the district court noted that the respondents had no constitutional right to improved procedures for handling civilian complaints, but because the frequency of abuse was so unacceptably high and such mistreatment would likely occur again, the court's ruling was a required first step in preventing future abuses (357 F. Supp. 1321). The Court of Appeals of the Third Circuit upheld the district court's decision, noting that "the revisions were... ordered because they appeared to have the potential for prevention of future police misconduct" (Rizzo v. Goode, 506 F. 2d 542, 548 [1974]).

The U.S. Supreme Court heard arguments in Rizzo v. Goode on November 11, 1975, and issued its ruling on January 21, 1976. In that ruling, the Supreme Court reversed both the district court and court of appeals decisions. The Supreme Court based its decision on two lines of reasoning. First, the Supreme Court concluded that the respondents had failed to demonstrate the requisite Article III case or controversy between individually named respondents and petitioners (Rizzo v. Goode, 423 U.S. 362 [1976]). Second, the Supreme Court found that the district court ruling amounted to an unwarranted federal judicial intrusion into the discretionary authority of the PPD to perform its duties.

Thus, over a period of approximately 6 years, federal courts (district, appeals, and the U.S. Supreme Court) heard cases and issued rulings involving use of force by PPD officers. This article considers the impact of two court rulings from Rizzo v. Goode and the change in Pennsylvania law on police shooting behavior in Philadelphia. Moreover, nearly a decade later, the Supreme Court issued a ruling in Garner that directly addressed use of deadly force by police. The timeline below summarizes the key events that are the focus of this article.

- February 1970: Rizzo v. Goode suit filed

- September 1970: COPPAR v. Rizzo suit filed 
- March 1973: district court issues injunction in Rizzo v. Goode

- June 1973: change in Philadelphia law limits deadly force use

- November 1975: Supreme Court hears arguments in Rizzo v. Goode

- January 1976: Supreme Court overturns Rizzo v. Goode injunction

- January 1985: Supreme Court issues ruling in Tennessee v. Garner

Specifically, this article addresses the following research questions:

- Does legislation make a difference?

- Did Pennsylvania's change in 1973 from a common-law fleeing felon statute to a defense-of-life statute affect the frequency and nature of police shootings in Philadelphia?

- Does judicial injunctive relief make a difference?

- Did the 1973 court injunction prohibiting brutality in Rizzo v. Goode affect the frequency and nature of police shootings in Philadelphia?

- Does a U.S. Supreme Court ruling make a difference? Did the 1985 ruling in Tennessee v. Garner affect the frequency and nature of police shootings in Philadelphia?

- Were the frequency and nature of police shootings affected when the Rizzo $v$. Goode injunction was lifted in 1976 ?

\section{DATA AND METHOD}

This study examines 982 police shootings in one site-Philadelphiaover a period of more than two decades, from 1970 through 1992 (see Table 1). The data presently consist of the actual police reports and investigations of all PPD shootings resulting in injury or death from 1970 to 1978 and from 1987 to 1992 and summary data (describing annual firearms discharge frequencies) from 1979 to 1986 . PPD discharge reports for the years 1979 to 1986 could not be located. I used archives of The Philadelphia Inquirer to determine monthly deadly force totals during those years. Because the PPD did not require reports or investigations into noninjurious shootings from 1970 to 1979 , the analysis includes only those shootings causing injury or death. Noninjurious shootings (shots fired that missed the intended target and injured no one), suicides, and shootings of animals are excluded.

\section{ARIMA}

The research uses ARIMA to test the impact of external events on levels of deadly force in Philadelphia. The goal of time-series analysis is to account for 
Table 1: Description of the Philadelphia Shooting Data by Year

\begin{tabular}{|c|c|c|c|c|}
\hline Year & $\begin{array}{l}\text { Number of } \\
\text { Shooters }\end{array}$ & $\begin{array}{l}\text { Number of } \\
\text { Incidents }\end{array}$ & $\begin{array}{c}\text { Number of } \\
\text { Suspects Injured }\end{array}$ & $\begin{array}{c}\text { Number of } \\
\text { Suspects Killed }\end{array}$ \\
\hline 1970 & 64 & 55 & 42 & 15 \\
\hline 1971 & 85 & 63 & 60 & 10 \\
\hline 1972 & 109 & 89 & 82 & 11 \\
\hline 1973 & 88 & 75 & 58 & 21 \\
\hline 1974 & 187 & 117 & 97 & 31 \\
\hline 1975 & 132 & 98 & 80 & 22 \\
\hline 1976 & 58 & 47 & 38 & 12 \\
\hline 1977 & 72 & 53 & 45 & 12 \\
\hline 1978 & 58 & 47 & 35 & 17 \\
\hline 1979 & 42 & 42 & - & - \\
\hline 1980 & 27 & 25 & - & - \\
\hline 1981 & 18 & 19 & - & - \\
\hline 1982 & 17 & 18 & - & - \\
\hline 1983 & 30 & 26 & - & - \\
\hline 1984 & 11 & 14 & - & - \\
\hline 1985 & 21 & 20 & - & - \\
\hline 1986 & 11 & 10 & - & - \\
\hline 1987 & 27 & 19 & 13 & 4 \\
\hline 1988 & 18 & 15 & 9 & 6 \\
\hline 1989 & 34 & 27 & 15 & 7 \\
\hline 1990 & 34 & 31 & 24 & 7 \\
\hline 1991 & 45 & 35 & 27 & 9 \\
\hline 1992 & 43 & 37 & 25 & 7 \\
\hline Total & 1,231 & 982 & 650 & 191 \\
\hline
\end{tabular}

NOTE: Dashes indicate that information on suspect injury was not systematically available for the years 1979 to 1986 .

a. Figures for suspect injury and death are incident based to ensure that suspect injuries are not counted more than once (i.e., two officers who shoot and kill the same suspect is counted as one death, not two).

or explain the values in the dependent variable, monthly levels of deadly force in this case (Babbie 1992). Because monthly totals of deadly force serve as the unit of analysis, there are 276 data points in the time series. There are two components to ARIMA. First, the analysis operationalizes the dependent variable (police shootings) as a time series, making inferences about the underlying process in the data (Box, Jenkins, and Reinsel 1994). The three-stage model-building process is identification, estimation, and diagnosis. In the identification stage, the autocorrelation and partial autocorrelation functions are examined. In estimation, parameter estimates are identified. Finally, the last stage involves examining the error residuals. 
The second stage of ARIMA, called impact assessment, involves assessing the impact of specific events on the time series data.

In the setting of intervention analysis, it is assumed that an intervention event has occurred at a known point in time $T$ of a time series. It is of interest to determine whether there is any evidence of a change or effect, of an expected kind, on the time series $Y t$ under study associated with the event. (Box, Jenkins, and Reinsel 1994, 462)

Impact assessment is conducted by adding the intervention as a dummy variable to the existing model identified in the first stage of ARIMA. Interventions vary by onset (abrupt or gradual) and duration (temporary or permanent).

This research considers the impact of four external events or interventions on police use of deadly force in Philadelphia:

1. June 1973 change in state law regarding justifiable homicide

2. March 1973 Rizzo v. Goode court injunction

3. Rizzo v. Goode court injunction overturned (January 1976)

4. Ruling in Tennessee v. Garner (March 1985)

\section{THE LIMITATIONS OF ARIMA}

Ideally, this study would conduct a multivariate time-series analysis, using other dependent variables such as arrests for violent crime, city population levels, and homicides. The research would chart changes in the other dependent variables over time, and their influence on levels of deadly force would become much more clear. However, in criminal justice research, these data are difficult to find at the monthly level, and their use goes beyond the scope of this research, which seeks a more modest application of time-series analysis to deadly force data.

Because of the data limitations, the current study suffers from a variety of threats to validity, most notably, history. Because the research relies only on police shooting data and it is simply not possible to control for all events occurring in the city during the study period at about the same time as the interventions, there is the opportunity for uncontrolled events to influence deadly force. Fortunately, ARIMA analysis is able to remove the impact of all other interventions, or confounders, that change gradually (Box, Jenkins, and Reinsel 1994). This facet of ARIMA goes a long way toward minimizing concerns over the potential confounding effects of other independent variables. Factors that change abruptly at approximately the same time as the interventions under study cannot be controlled by ARIMA and still represent 
a threat to validity. However, based on my knowledge of Philadelphia's history and an independent review of newspaper archives during the study period, there appears to be no known confounding variable that threatens the validity of the analysis presented here. ${ }^{5}$

Nevertheless, prior to the ARIMA analysis, the article seeks to address this potential weakness in the analysis by describing annual rates (per 100,000 residents) of several important environmental influences, including population level, sworn police personnel, violent crime arrests, and homicides and comparing them to the annual rate of deadly force. Although not as statistically sound as the time-series analysis, the discussion represents an effort to explore other environmental processes and patterns linked to deadly force, thereby addressing several potentially important historical threats and supporting the validity of the study.

\section{ANALYSIS AND RESULTS}

\section{ENVIRONMENTAL COVARIATES OF DEADLY FORCE}

As part of an effort to address potential historical threats to validity, Table 2 shows annual city population levels and annual rates (per 100,000 Philadelphia residents) of sworn police, arrests for violent crimes, homicides, and police shootings. The research can draw conclusions regarding the impacts of these other potential influences on deadly force simply by examining the rates and comparing the trends over time. Similar trends between a factor and deadly force indicate that it may be exerting an influence. If the rates look completely different, the findings suggest that the threats to validity are not having an effect on levels of deadly force.

Table 2 shows annual police shooting rates per 100,000 city residents over time. There is a general upward trend during the first half of the 1970s, with a peak in 1974 (at 6.35 per 100,000 residents) and a general decline through the rest of the decade (2.46 in 1979). Annual rates dropped notably in 1980 (1.49 per 100,000) and remained at that level or below through 1988. However, the rate begins to increase in 1989 (1.63 per 100,000) through the end of the study period (2.35 per 100,000 in 1992).

Table 2 also shows a remarkable decrease in city population over the entire study period, particularly from 1970 to 1980 (from 1.95 million in 1970 to 1.68 million in 1980). Population in the city of Philadelphia continued to drop throughout the 1980s as well. Notably, the dramatic decrease in population from 1970 to 1980 occurs when levels of deadly force are highest. The 
Table 2: Annual City Population and Annual Rates of Sworn Police Personnel, Arrests for Violent Felony Offenses, and Homicides per 100,000 Residents in Philadelphia, 1970 to 1992

\begin{tabular}{|c|c|c|c|c|c|}
\hline Year & $\begin{array}{c}\text { City } \\
\text { Population }\end{array}$ & $\begin{array}{c}\text { Police } \\
\text { Shooting } \\
\text { Rate }\end{array}$ & $\begin{array}{c}\text { Sworn Police } \\
\text { Personnel } \\
\text { Rate }\end{array}$ & $\begin{array}{c}\text { Violent } \\
\text { Felony Arrest } \\
\text { Rate }\end{array}$ & $\begin{array}{c}\text { Homicide } \\
\text { Rate }\end{array}$ \\
\hline 1970 & $1,948,609$ & 2.82 & 399.26 & 324.54 & 18.06 \\
\hline 1971 & 1,921,866 & 3.28 & 393.16 & 414.08 & 22.63 \\
\hline 1972 & $1,895,123$ & 4.70 & 431.79 & 397.71 & 21.79 \\
\hline 1973 & $1,868,380$ & 4.01 & 429.57 & 396.28 & 23.01 \\
\hline 1974 & $1,841,637$ & 6.35 & 447.70 & 471.65 & 24.11 \\
\hline 1975 & $1,814,894$ & 5.40 & 445.48 & 536.39 & 23.97 \\
\hline 1976 & $1,788,151$ & 2.63 & 456.00 & 459.41 & 18.96 \\
\hline 1977 & $1,761,408$ & 3.01 & 464.86 & 450.15 & 18.34 \\
\hline 1978 & $1,734,665$ & 2.71 & 473.23 & 489.32 & 20.23 \\
\hline 1979 & $1,707,922$ & 2.46 & 462.73 & 506.58 & 22.54 \\
\hline 1980 & $1,681,175$ & 1.49 & 443.38 & 564.31 & 25.99 \\
\hline 1981 & $1,686,834$ & 1.13 & 442.96 & 615.24 & 21.52 \\
\hline 1982 & $1,687,557$ & 1.07 & 437.14 & 640.57 & 19.67 \\
\hline 1983 & $1,692,364$ & 1.54 & 426.50 & 608.97 & 18.44 \\
\hline 1984 & $1,667,545$ & 0.84 & 424.28 & 614.08 & 15.77 \\
\hline 1985 & $1,640,102$ & 1.22 & 424.73 & 615.27 & 16.71 \\
\hline 1986 & $1,645,144$ & 0.61 & 417.47 & 638.18 & 20.85 \\
\hline 1987 & $1,649,364$ & 1.15 & 406.10 & 641.40 & 20.49 \\
\hline 1988 & $1,657,285$ & 0.91 & 365.84 & 607.08 & 22.39 \\
\hline 1989 & $1,652,188$ & 1.63 & 379.07 & 604.29 & 28.81 \\
\hline 1990 & $1,585,577$ & 1.96 & 406.67 & 649.73 & 31.53 \\
\hline 1991 & $1,585,577$ & 2.21 & 406.41 & 657.11 & 27.75 \\
\hline 1992 & $1,577,610$ & 2.35 & 398.07 & 644.77 & 26.94 \\
\hline
\end{tabular}

annual rate of sworn police per 100,000 city residents somewhat resembles the police shooting rate. There are dramatic increases in the 1970s (from 399 per 100,000 in 1970 to 473 per 100,000 in 1978), but the level peaks in 1978 rather than 1974. From there, the rate decreases sharply through 1988 (365 per 100,000), when it begins to increase again. Thus, the annual rate of sworn police may be associated with annual rates of deadly force: As the number of sworn police increases, so does the number of police shootings. ${ }^{6}$

Annual rates of arrests for violent crime and homicides per 100,000 city residents seem less associated with annual rates of deadly force. Annual rates of violent crime arrests, a good measure of police exposure to danger, appear to move in the opposite direction of deadly force annual rates throughout most of the study period. The rate is relatively low yet increasing in the 1970s, from 324 in 1970 to 450 in 1977, but it increases dramatically from 1978 to 
1982, when levels of deadly force decreased. Both annual rates are relatively stable through the 1980s, and then both increase beginning in 1988.

The annual rate of homicides per 100,000 city residents is a good measure of public violence. The annual homicide rate seems to move independently of annual deadly force rates as well. The annual homicide rate is relatively stable throughout the 1970s, from 18 per 100,000 in 1970 to 22 per 100,000 in 1979 , when rates of deadly force are most volatile. The annual homicide rate has a peak in 1980 (at 26 per 100,000), when the deadly force rate has reached a 10-year low. The annual homicide rate drops off in the early 1980s and then increases notably from 1985 to 1988 , when the annual deadly force rate is at its lowest. After 1988, the annual homicide and police shooting rates both increase through the end of the study period.

These factors represent four potential external influences on deadly force (identified in prior research) or threats to validity. Through simple eyeballing techniques, only the levels of sworn police personnel seem to be associated with levels of deadly force. Police use of deadly force seems to operate independently of city population levels, arrests for violent crimes, and homicides, although rates of arrest and homicide appear to increase in the late 1980s when levels of deadly force also increased. The dynamic nature of these important external influences represents the context in which police shootings occurred. With this initial analysis of potential external influences as a backdrop, time-series analysis investigates the impact of two types of external discretion control policies-formal law change and judicial intervention.

\section{TIME-SERIES MODEL IDENTIFICATION}

The goal of the identification phase is to identify a tentative model for the time series-monthly numbers of police shootings-based on the preintervention data (shown in Figure 1). ${ }^{7}$ Because models are estimated on preintervention data, the length of the time series available for estimation varies for each intervention. For example, because the Garner ruling was handed down in March 1985, the tentative model for that intervention would be estimated on the 182 months prior to that point (from January 1970 to February 1985). However, Box, Jenkins, and Reinsel (1994) stated that a minimum of 50 data points are required for time-series model identification. Unfortunately, in the case of the state law change (June 1973) and the district court injunction (March 1973), fewer than 50 points are available for analysis (41 and 38 data points, respectively). Rather than develop models with insufficient data, I heed the concerns of Box, Jenkins, and Reinsel (1994) and apply the model identified for the third intervention (the Supreme Court ruling in 


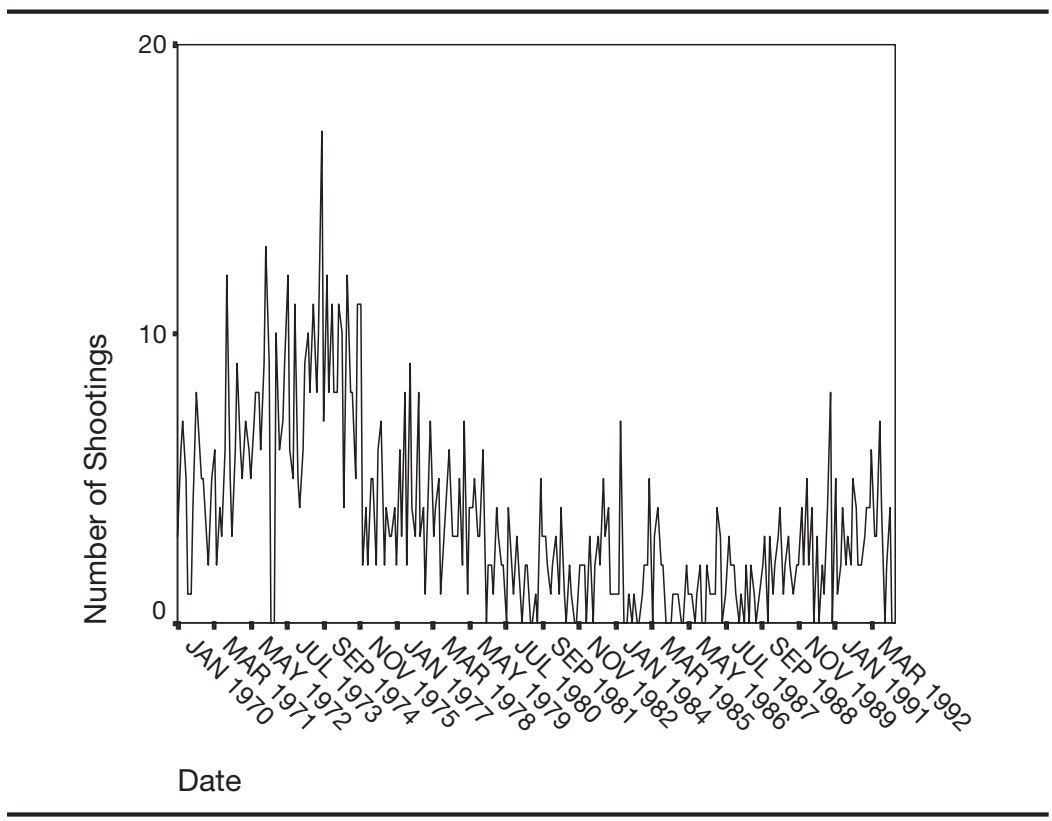

Figure 1: Monthly Totals of Police Shootings in Philadelphia, 1970 to 1992

January 1976) to those two earlier interventions as well. Estimated on 72 available data points, the identified model for the three interventions (state law change and the court rulings in Rizzo v. Goode) is $(0,1,1)(0,1,1)_{12}$, with regular and seasonal moving averages (see Box, Jenkins, and Reinsel 1994 for a more in-depth discussion of ARIMA modeling). For the Garner ruling, time-series identified the model $(0,1,1)(1,1,0)_{12}$ with moving average and seasonal auto-regressive components. ${ }^{8}$

\section{ARIMA WITH THE LAW CHANGE}

Time series examined the impact of the change in Pennsylvania law using a dummy variable to represent the June 1973 legislative change, with an abrupt temporary pattern (see Box, Jenkins, and Reinsel 1994 for a discussion of the different types of onset and duration of interventions). To examine the impact of the change in statutory law on police use of deadly force in Philadelphia, the existing model $(0,1,1)(0,1,1)_{12}$ is run with the independent variable as an additional component. ${ }^{9}$ This analysis indicates that the June 1973 change in statutory law governing justifiable homicide did not have a 
significant impact on police use of deadly force in Philadelphia. This finding certainly falls in line with much of the prior research on legislation as a form of discretion control, including Waegel's (1984) study of the same law change and its effect on use of deadly force by the same police department.

\section{ARIMA WITH THE DISTRICT COURT INJUNCTION}

To examine the impact of the district court injunction on police use of deadly force in Philadelphia, the existing model $(0,1,1)(0,1,1)_{12}$ was run with the independent variable. ARIMA uncovered an abrupt, temporary intervention lasting for 33 months (from March 1973 to November 1975). However, the results indicate that levels of deadly force actually increased following the issuance of the injunction that sought to control police field behavior (the $B$ weight for the independent variable is positive, 0.51 ).

\section{A NOTE ON THE TIME SEQUENCE OF} THE LAW CHANGE AND INJUNCTION

The issuance of the district court injunction and the change in Pennsylvania state law occurred within a few months of one another (March and June 1973, respectively). Although ARIMA allows the researcher to specify the onset of an intervention to a given month, it is sometimes difficult to interpret findings when independent variables occur so close in time (i.e., multicollinearity). Specifically, one significant finding may be interpreted as an immediate impact resulting from Independent Variable $A$ (where the intervention and impact occur in the same month) or as a gradual impact resulting from Independent Variable $B$ (where the impact begins at some point after the intervention). In most cases, it would be quite difficult, if not impossible, to disaggregate the data and flesh out the impacts of the two different phenomena occurring so close in time. ${ }^{10}$

The interpretation problems are not a serious issue in this research because of the timing of the significant impact. The significant impact began in March 1973, during the same month as the district court injunction and fully 3 months before the state law change. Because the impact occurred prior to the law change, the researcher feels confident attributing it to the injunction. ${ }^{11}$

\section{ARIMA WITH THE SUPREME COURT RULING IN RIZZO v. GOODE}

ARIMA analysis with the Supreme Court ruling discovered an abrupt, permanent intervention lasting through the end of 1992. Thus, it would seem 
that the Supreme Court ruling that overturned the Rizzo v. Goode injunction had a statistically significant impact on police shooting behavior. However, the results indicate that levels of deadly force decreased following the Supreme Court ruling. This finding seems counterintuitive, given that the ruling overturned the Rizzo v. Goode injunction and essentially gave officers greater discretion to use deadly force.

\section{ARIMA WITH THE SUPREME COURT \\ RULING IN TENNESSEE V. GARNER}

ARIMA analysis with the Garner decision found a gradual, permanent impact beginning in August 1985 and lasting through the end of the study period. Results suggest that the Garner decision led to a significant decrease in levels of deadly force among Philadelphia police officers.

\section{A CLOSER LOOK AT THE STRENGTH OF INTERVENTION IMPACTS}

Two concerns still remain regarding the analysis described above. First, the dependent variable is a count that for some months is zero, which creates problems for normal assumptions of ARIMA and raises questions about the meaning of the autocorrelation function. Second, are the statistically significant impacts that have been identified by ARIMA large enough to be important for police policy and practice?

First, in an effort to address the problems associated with zeroes in the dependent variable, I created a new quarterly version of the data, with each data point representing a 3-month total of police shootings (instead of 1month totals). Impact assessment was conducted with this 3-month, smoothed version of the data (in which there are no zero data points) to determine if the identified impacts still existed or if they were perhaps a product of the problems associated with the monthly data (i.e., the zero data points). The analysis with the quarterly data confirmed the existence of the significant impacts associated with the district court injunction and the Garner decision. The impact associated with the Supreme Court ruling in Rizzo v. Goode was identified but was just short of being statistically significant (intervention's probability was .07). Although this additional analysis does not completely eliminate concerns over the effects of zero data points on the results, it does support the findings of significant impacts associated with the interventions.

Second, ARIMA analysis identified significant impacts associated with three of the four interventions tested: the district court injunction and the Supreme Court rulings in Rizzo v. Goode and Tennessee v. Garner. An 


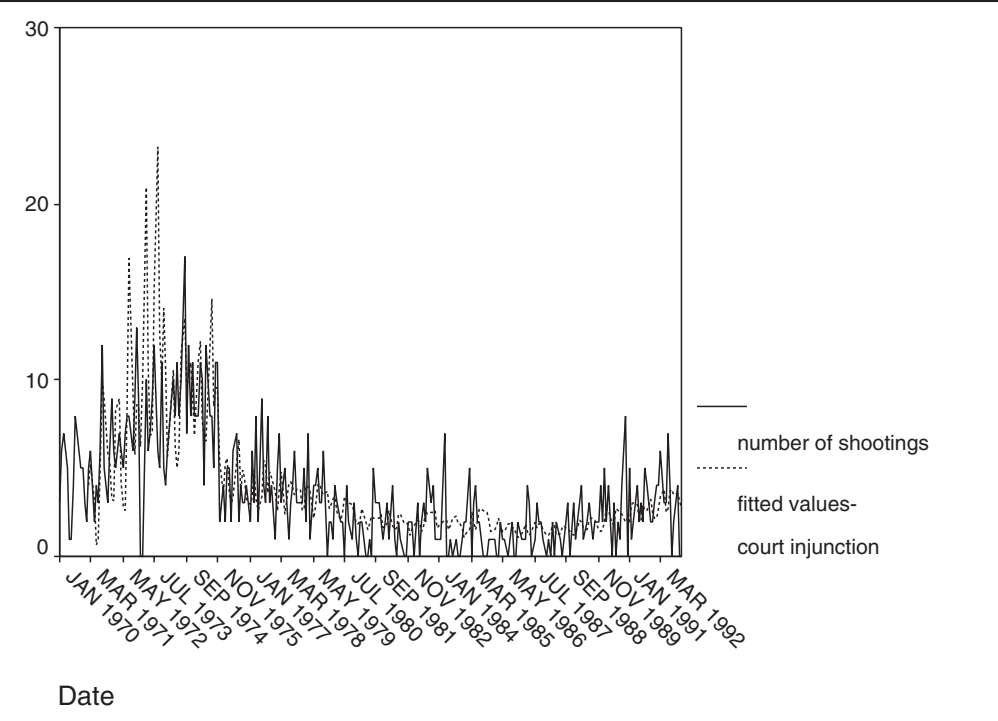

Figure 2: Fitted Values Overlaid on the Original Data for the District Court Intervention

alternative way to judge the importance or strength of these particular impacts is to overlay the fitted models (with interventions included) on the raw data. This additional step takes the findings to another level by testing whether the identified impacts remain significant and, in effect, tests whether the impacts are large enough to matter in terms of police policy. Figures 2, 3, and 4 show plots of the original data, overlaid with fitted values for the district court injunction, Supreme Court ruling, and Tennessee v. Garner models. Although not methodologically rigorous, this analysis provides a visual sense of how large the effects are in real terms. Review of the figures indicates that although the effects of the interventions were statistically significant, in practical terms they are likely not large enough to be practically significant.

\section{DISCUSSION}

This article attempted to test the impact of external discretion control methods on police use of deadly force with a different strategy by using ARIMA with monthly levels of deadly force for a period of over two decades in Philadelphia. Although the data are not ideal (aggregate data from 19791986) and the analyses suffer from historical threats to validity, a number of 


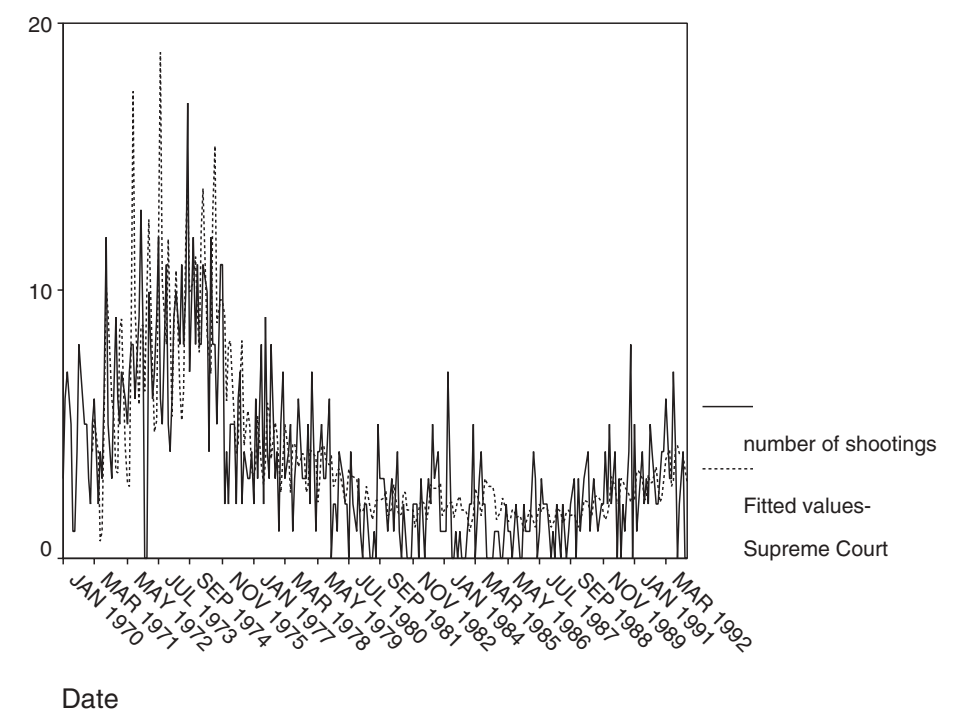

Figure 3: Fitted Values Overlaid on the Original Data for the Supreme Court Intervention

interesting findings emerge. First, at least on an aggregate level over the entire study period, annual rates of police shootings do not appear to be associated with several important environmental influences, including population level, arrests for violent felony offenses, and homicides, and appear only slightly associated with the rate of sworn police personnel. During the late 1980s, however, rates of violent felony arrests, homicides, and police shootings all increase together. Second, the analysis found that the legislative change did not have a significant impact on levels of deadly force in Philadelphia. These results support prior research indicating that state law is not an effective control of deadly force discretion (Fyfe 1988).

Third, with judicial injunctive relief, the research discovered two significant impacts on levels of deadly force, but both impacts are in the opposite direction from what would intuitively be expected. Levels of deadly force actually increased following issuance of the district court injunction, suggesting that the court ruling was ineffective in controlling police shooting behavior. ${ }^{12}$ Time-series analysis with the Supreme Court ruling found a significant impact, indicating that PPD officers used deadly force less frequently after the Court overturned the lower court decision and lifted the injunction. However, additional analysis suggests that these effects were not large enough to be practically meaningful. 


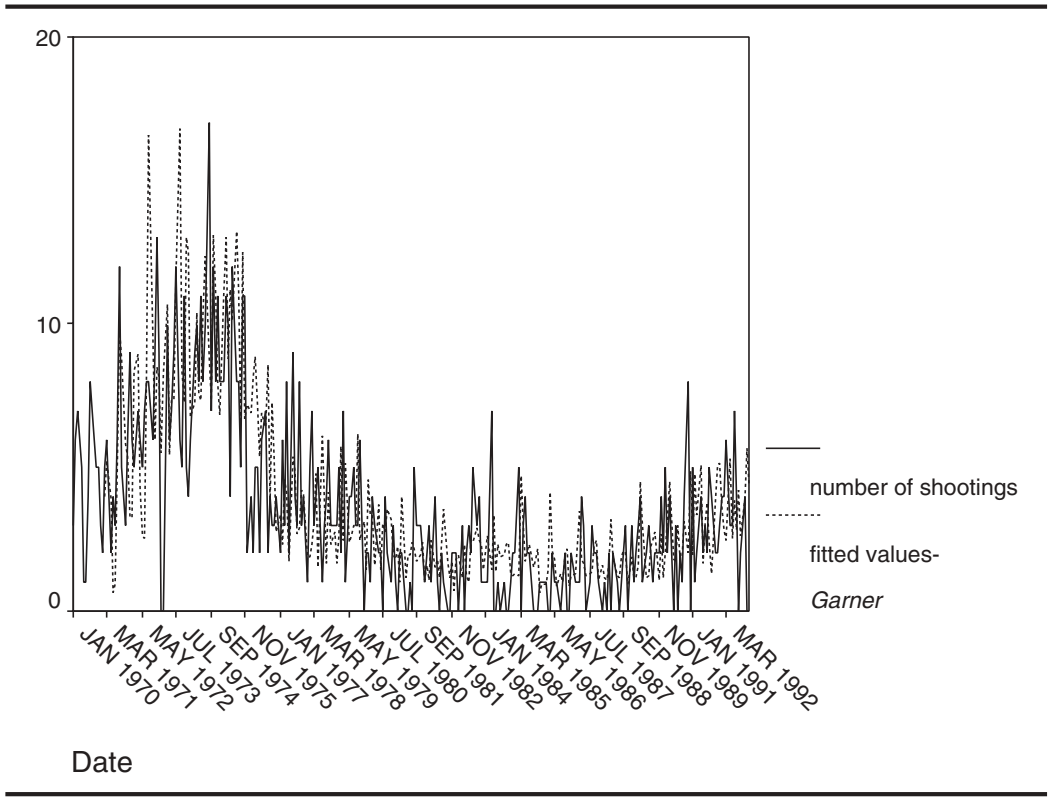

Figure 4: Fitted Values Overlaid on the Original Data for the Garner Intervention

Fourth, the Supreme Court ruling in the Garner case appears to have had a statistically significant effect on use of deadly force by Philadelphia police officers, although the finding was not strong enough to emerge in the additional analysis. Taken as a whole, the findings indicate that direct external efforts to control deadly force in Philadelphia were not overly successful.

\section{THE INTERNAL WORKING ENVIRONMENT AS AN INTERVENING FACTOR}

Several of the findings above should be interpreted within the context of changes in another important aspect of police working environments: internal administrative policy. More specifically, two important administrative deadly force policy changes occurred during the study period that also affected police deadly force decision making. Shortly after the Pennsylvania law was changed in 1973, the PPD responded by adopting an administrative policy that conformed to the new state law. However, a review of shooting reports during that time raises serious questions about the degree to which this policy was followed and enforced. ${ }^{13}$ 
In December of 1974, the PPD removed all ambiguity by abolishing the restrictive policy it had put in place a year earlier. Police Commissioner Joseph O'Neill and Mayor Rizzo argued that the state legislature had failed to adequately define forcible or violent felonies and that, until they did so, the state law was invalid (United States Civil Rights Commission 1979, 181-83, 215-18). Consequently, the department abolished the restrictive deadly force policy, and the PPD operated without a formal policy for the next 6 years.

White (2001) found that the abolition of the restrictive administrative policy in 1974 was followed by a statistically significant increase in police shootings (using ARIMA). Perhaps more important, findings suggested that the PPD officers were not following the administrative policy prior to its removal, and the department was not holding them accountable for their violations (White 2001). Essentially, the administrative policy had been routinely superceded by the police leadership's customs and informal practices in the months and years prior to the change.

The increase in deadly force levels associated with the district court injunction may be a result of the internal police working environment (e.g., organizational subculture) and the formal removal of the restrictive administrative policy in 1974. The injunction represented a formal directive from the court ordering changes in how the police department conducted its business on a daily basis. The injunction may have failed to stimulate change in officer field behavior, particularly use of their firearms, because the informal organizational rules remained unchanged. Moreover, the internal environment may also be responsible for the nonsignificant findings associated with the Pennsylvania law change. Line officers tend to behave in accordance with the informal norms established by peers and supervisors, and in the case of the PPD in the 1970s, the organizational environment tolerated use of firearms in resolving a broad range of police-citizen encounters (Fyfe 1980b, 1988; White 2001).

The second counterintuitive finding involved a permanent decrease in use of deadly force (at least through the end of the study period in 1992) associated with the 1976 Supreme Court ruling overturning the Rizzo v. Goode injunction. Although the impact did not withstand additional testing, its direction and implications warrant further consideration. First, the lack of a short-term increase in police shootings after the Supreme Court ruling (until 1980, the intuitive finding) may be a consequence of the organizational environment that existed during that time. Essentially, few noticed when the injunction was lifted because they were not adhering to it anyway.

Second, the long-term decrease may also be explained, in part, by a change in departmental deadly force policy. By the end of 1979, Rizzo had served two terms as mayor, which was all that the city's charter permitted. 
During that same year, the Civil Rights Division of the U.S. Department of Justice filed suit against the PPD for tolerating brutality. ${ }^{14}$ Subsequently, Bill Green won the mayoral election in 1979, and as part of Green's effort to ease racial tensions, he brought in a reform police commissioner (Morton Solomon) who initiated several organizational changes, including vigorously enforced restrictions on the use of deadly force. The 1980 administrative policy was essentially the same policy that the PPD operated under through the end of 1974 before it was removed.

Using ARIMA, White (2001) found that the 1980 policy change was followed by an immediate and substantial decrease in the use of deadly force by PPD officers, lasting approximately 10 years. Fyfe (1988) concurred, noting that annual PPD homicide rates were 2.09 per 1,000 officers while Rizzo was police commissioner, 2.29 while he was mayor, and 1.05 after he left office. The permanent decrease associated with the Supreme Court ruling may be at least partially explained by the administrative policy change that occurred in 1980.

Importantly, the statistically but not practically significant findings associated with the Garner ruling should also be interpreted in the context of the 1980 administrative policy change. The policy adopted and vigorously enforced in 1980 met the requirements laid out in the Garner ruling 5 years later. Simply put, the failure to find a large decrease in PPD shootings in 1985 is likely explained by the fact that PPD officers were already being held to the Garner standard and had been for 5 years prior to the ruling.

\section{WHEN CAN EXTERNAL DISCRETION CONTROL POLICIES AFFECT DEADLY FORCE DECISION MAKING?}

Findings above suggest that external efforts to control deadly force discretion (at least in Philadelphia) have been relatively unsuccessful but that those findings must be interpreted in the context of other changes in the internal working environment. When considering why formal law change did not produce its desired effect in police deadly force practices in the Philadelphia context, it appears that such an approach failed to overcome the influence of aspects of the internal police environment in shaping police practices in the field. Simply put, the restrictive state law was not enforced. The research identified several incidents in which the law was apparently violated but no incidents in which officers were prosecuted for such violations. Reluctance among Philadelphia's district attorneys to prosecute officers for violations of state law stems from a number of issues. First, judges in Philadelphia are elected on a popular ballot, usually with endorsements from the Fraternal 
Order of Police and the same political parties to which the district attorneys belong, which limits the possibility of getting convictions.

Second, prosecuting officers for their use of deadly force meant taking on Rizzo's PPD. Nearly half of the study period for this research occurs during the "Rizzo era," with Rizzo as both police commissioner and mayor. During his reign in Philadelphia, Rizzo dominated city politics and exerted considerable influence over the PPD.

Last, during the Rizzo years, the district attorney's office in Philadelphia served as a stepping-stone to higher office and was held by people who could not afford to alienate their parties, the police, or the voters generally. In fact, the district attorneys in those years were Arlen Specter and Ed Rendell, whose political presence in Philadelphia would likely have been jeopardized had the Fraternal Order of Police and Rizzo fought their attempts to move into higher offices.

Although this finding on the limited effect of statute on use of deadly force is consistent with prior research, it should be interpreted with care because this study did not test the effects of a vigorously enforced statute on officers' discretion. Essentially, the new statute represented no real change because it was not enforced. It may be difficult to find a place where such a statute is enforced, but before conclusions can be drawn regarding whether statutes make a difference, researchers must find more vigorous district attorneys than those in Philadelphia.

Like the law change, the judicial rulings failed to significantly change deadly force decision making among PPD officers, at least in part because of the prevailing norms of the internal working environment. In the 1970s, the rulings associated with Rizzo v. Goode were likely outweighed by the informal norms of the department that tolerated heavy-handed tactics, including use of firearms (see also Fyfe 1988; Skolnick and Fyfe 1993). By the mid1980s, the internal working environment of the PPD had changed dramatically to the point where the requirements laid out in Garner simply duplicated prevailing administrative deadly force standards for Philadelphia police officers.

Nevertheless, consideration of aspects of judicial intervention highlights its potential as an effective control, particularly in comparison with state law. First, the directives of legislation are generally vague, leaving its application to practice — even under a willing police administration —open to interpretation and to prosecutorial restraint in charging officers. The substance of judicial decisions is much more clear and direct. For example, the district court order in the Rizzo v. Goode case detailed very specific requirements that PPD was to meet. In Garner, the Supreme Court clearly stated that shootings of nonviolent, fleeing suspects were unconstitutional. 
Second, in the case of judicial intervention, the courts hold the police department directly accountable for its actions if police officers violate the judicial rulings. Judges can provide immediate and foreseeable consequences to the police commissioner and officers for violations of their rulings (more so in cases of injunctive relief than in U.S. Supreme Court rulings). In contrast, those responsible for enforcing state law (e.g., the district attorney's office) have been reluctant to prosecute officers whose actions violate the law, likely a consequence of their need to maintain a positive working relationship with police (Fyfe 1988). In simpler terms, often there has been no "hammer" for violating the law.

Third, the potential greater influence of a court order or ruling may also be a result of enforcement mechanisms and standards of proof. Statutes criminalizing police use of force require district attorneys to make a political decision to charge officers and then to prove cases beyond a reasonable doubt. The court decisions, on the other hand, typically involve civil cases brought by victims who are eager rather than reluctant to pursue the case and do not need to meet the guilt beyond a reasonable doubt standard. The civil standard is preponderance of the evidence. In short, district attorneys rarely prosecute and convict police officers who use excessive force. In contrast, shooting victims frequently sue police who use deadly force and win these lawsuits.

Last, the effectiveness of court rulings may be a result of their distance from local influences. State prosecutions occur in the context of the local political environment, whereas court intervention, particularly from state and federal courts, is more removed and less subject to the local political climate. This explanation argues for private civil litigation in federal courts as a remedy for local abuses, as well as federal interventions.

In sum, with court intervention, the visible presence of the judge and the accountability he or she provides may translate into accountability within the police department. This accountability across the board, as well as distinct and perceptible consequences for transgressions and the limited role of local influences, may empower judicial intervention as a more effective control on police field behavior than state law.

Thus, it appears that the effectiveness of both state law and judicial intervention as external influences on police use of deadly force are, to a certain degree, dependent on the police department's awareness and acceptance of the discretion control policy. Certainly, the case of Philadelphia in the 1970s and 1980s represents a less-than-ideal test for measuring the actual effectiveness of external discretion control policies because of the dynamic changes that occurred in the internal working environment. Those internal changes tended to overshadow or outweigh any impact the law change or court rulings 
may have had and hinder conclusions about their effectiveness as discretion control mechanisms.

\section{ENVIRONMENTAL DETERMINANTS}

\section{EMERGE AS INFLUENCES ON DEADLY FORCE}

Time-series analysis of the 1980 deadly force policy change (the intervening factor affecting the Supreme Court ruling) shows that the impact of the intervention ends in November 1989 (White 2001). This finding suggests that the nature and/or frequency of police shootings changed during that month, ${ }^{15}$ and review of available departmental data reveals no notable change in deadly force policy, formal or otherwise, during that time. Review of newspaper archives also reveals no particular external or internal events that would, theoretically, explain the change in deadly force levels.

There were, however, a number of notable shifts among external environmental factors that may have affected deadly force levels (see Table 2). First, as noted earlier, during the late 1980s important shifts occurred in the annual rates of sworn police personnel, arrests for violent felony offenses, and homicides per 100,000 residents. The rate of sworn police per 100,000 residents increased throughout the 1970s, peaking in 1978 before dropping during the 1980s. However, starting in 1989, there is an increase in the annual rate of sworn personnel per 100,000 residents for the first time in more than a decade.

Table 2 shows that the annual rate of arrests for violent felony offenses, a good measure of police exposure to danger, had been declining throughout the latter half of the 1980s, particularly after 1982. In fact, the annual rate of arrests bottomed out in 1989 but then quickly rose from 1990 to 1992. Increases in violent felony arrests after 1989, and the concomitant increase in police exposure to danger, may have contributed to the shifting patterns in use of deadly force in late 1989 .

From 1981 to 1988 , the annual homicide rate per 100,000 residents remained fairly stable, ranging from 16 to 22 (see Table 2). ${ }^{16}$ In 1989, however, the annual rate jumps to 29 homicides per 100,000 residents, then peaks at 31 in 1990 before dropping off in 1991 and 1992, although the rate is still at its highest level since 1980. This increase in homicides also may have contributed to the change in deadly force patterns during this time.

Further analysis shows that post-1989 incidents differed in three additional important ways. First, the data indicate that officers involved in incidents after 1989 are younger and more heavily armed than before. ${ }^{17}$ Second, post-1989 incidents appear more likely to be drug involved. From 1987 to 
November 1989, no officers assigned to the stakeout unit and only one officer assigned to narcotics discharged their firearms. ${ }^{18}$ From December 1989 through the end of the study period, four officers assigned to stakeout and 11 officers assigned to narcotics used deadly force (nearly one fifth of all shootings post-1989). Third, precipitating events may have changed as well after 1989. The data indicate that the percentage of incidents beginning with an officer observing some behavior or acting on citizen information increased by $13 \%$.

The well-publicized nationwide War on Drugs, an external policy directive from the White House, may be partly responsible for the changing nature of police shooting incidents in Philadelphia. With its emphasis on targeted and proactive enforcement of drug laws, the War on Drugs increased police officer exposure to the well-documented link between drug dealing and gun violence. The increased exposure to danger, also reflected in increases in violent felony arrests, may have affected deadly force levels in Philadelphia.

\section{CONCLUSION}

This study examined the impact of external influences on the use of deadly force from a different perspective, using ARIMA and 23 years of shooting data. The analyses considered two general types of external influences: direct efforts to affect deadly force decision making and more general, communitylevel influences. The research, in short, demonstrates the difficulty of attempting to control police shooting discretion through external measures, particularly when there are dynamic changes in the internal environment as well. Nevertheless, consideration of aspects of state law and judicial intervention as deadly force controls indicates that they have the potential to affect deadly force, although judicial intervention may hold more promise. Results here suggest that both external control mechanisms can be outweighed by the internal police working environment. Finally, the suspected influence of community-level external factors during the late 1980s in Philadelphia supports prior deadly force research (e.g., Kania and Mackey 1977; Fyfe 1980a, 1982; Geller and Karales 1981; Matulia 1985; Alpert 1989; Liska and Yu 1992; Sorenson, Marquart, and Brock 1993) and suggests that external environmental factors can indirectly affect deadly force discretion and may overcome the controlling influence of the internal working environment. The finding also indicates that the external working environment's influence is more often associated with general environmental factors that exert an 
incidental or indirect impact on police shooting behavior rather than those factors directly seeking to control it.

\section{NOTES}

1. In encounters in which the officer was facing grave danger (assailants armed with guns, knifes, or other weapons), situational factors largely dictated an officer's decision to use deadly force and outweighed the relative influence of the working environments. In situations in which police officers used deadly force against physically assaultive and nonassaultive suspects, the internal and external working environments played a more prominent role in elective encounters, whereas situational factors were less important (White 2001).

2. Subsequently, Sherman and Langworthy (1979) noted that the coroner-derived data used by Kania and Mackey (1977) are of questionable validity primarily because coroners frequently placed police shootings in the wrong category.

3. This article examines the same 1973 change in Pennsylvania state law as Waegel (1984).

4. The Court said,

Appropriate revision of police manuals and rules of procedure spelling out in some detail, in simple language, the "do's and don'ts" of permissible conduct in dealing with civilians.... (2) Revision of procedures for processing complaints against police, including (a) ready availability of forms for use by civilians in lodging complaints against police officers; (b) a screening procedure for eliminating frivolous complaints; (c) prompt and adequate investigation of complaints; (d) adjudication of non-frivolous complaints by an impartial individual or body, insulated so far as practicable from chain of command pressures, with a fair opportunity afforded the complainant to present his complaint, and to the police officer to present his defense; and (3) prompt notification to the concerned parties. (COPPAR v. Rizzo 1973, 1321)

5. One potential confounding factor is the May 1985 siege on the MOVE house. After an unsuccessful raid, Philadelphia police fired more than 10,000 rounds at the house and, later that day, dropped an explosive device on the roof. A fire ensued and burned down an entire city block. Eleven MOVE members were killed, including five children. White (1999) tested the impact of that event on levels of deadly force in Philadelphia (using the same data and analysis used here) and found that the event had no effect on police shooting behavior.

6. When Frank Rizzo was police commissioner and mayor during the 1970s, he constantly argued for more police. During his tenure, the number of police personnel swelled to more than 8,000 .

7. Table 2 shows annual rates of police shootings per 100,000 residents. Time-series analysis uses monthly totals of police shootings as the unit of analysis.

8. In addition to the model-building process for the existing data, a model was constructed with another version of the data in which monthly totals during the years 1979 to 1986 are increased by $40 \%$. This additional model was constructed to test the impact of reliance on newspaper archives for the years for which police-generated data are missing. Theoretically, if the same model is identified for both versions of the data, the reliance on newspaper archives is not 
as methodologically troubling. Although not presented here, analysis shows that the same model is identified with the adjusted data as with the existing data. This finding suggests that reliance on newspaper archives for the years 1979 to 1986 does not weaken the study's analysis, findings, and conclusions.

9. Multiple variations of all other impact patterns were tested, including gradual permanent and abrupt permanent patterns, but none were found to be significant.

10. The correlations among the dummy intervention variables can be calculated to help assess the potential for collinearity problems. Using Pearson's $R$, the correlations for the interventions are as follows:

Law change and district court injunction (.164)

Law change and Supreme Court ruling (-.102)

Law change and Garner ruling (-.042)

District court injunction and Supreme Court ruling (-.620)

District court injunction and Garner ruling (-.254)

Supreme Court ruling and Garner ruling (.410)

11. Interrupted time-series analysis (ARIMA) does not allow for the testing of impacts that would begin prior to the actual intervention, or independent variable. The onset of the impact of an intervention can be either immediate (same month) or gradual (at some point after the intervention).

12. Although the court sought to affect police use of force more generally, use of deadly force certainly was part of the pattern of police behavior the court targeted.

13. Certainly, this restrictive shooting policy did not follow ex-Police Commissioner/Mayor Frank Rizzo's personal philosophy on the treatment of criminals: spacco il cappa, in his words, or "to bust their heads" (It was a long and colorful career 1991, 1-A).

14. This was the first time ever that the Department of Justice had filed suit against a police department for tolerating brutality.

15. In fact, there were nearly twice as many shootings from December 1989 through the end of 1992 (107) as there were from January 1987 through November 1989 (57, both periods approximately 3 years). There was also a notable increase (15\%) in the percentage of shooting incidents involving assailants armed with guns.

16. Kania and Mackey (1977) argued that police violence is related to violence in the community. That is, in violent areas of town, police are more likely to use violence themselves.

17. The median age for post- 1989 shootings is 32 , compared to 36 for shooters in 1987-1989. Post-1989 shooters more frequently used semiautomatic pistols rather than the .38 caliber revolver, which was the standard issue throughout the study period (semiautomatic: $31 \%$ vs. $7 \%$ ).

18. The stakeout unit is responsible for serving warrants and conducting high-risk searches. They are, in effect, the Philadelphia Police Department's SWAT team.

\section{REFERENCES}

Alpert, G. P. 1989. Police use of deadly force: The Miami experience. In Critical issues in policing, edited by R. G. Dunham and G. P. Alpert, 480-96. Prospect Heights, IL: Waveland. 
American Law Institute. 1931. ALI Proceedings, 186-87 (statement of Professor Mikell).

Babbie, E. 1992. The practice of social research. Belmont, CA: Wadsworth.

Box, G. E. P, G. M. Jenkins, and G. C. Reinsel. 1994. Time series analysis: Forecasting and control. 3d ed. Upper Saddle River, NJ: Prentice Hall.

Fyfe, J. J. 1979. Administrative interventions on police shooting discretion: An empirical examination. Journal of Criminal Justice 7:309-24.

- 1980a. Geographic correlates of police shooting: A microanalysis. Journal of Research in Crime and Delinquency 17:101-13.

. 1980b. Philadelphia police shootings, 1975-78: A system model analysis. Report for the Civil Rights Division, U.S. Department of Justice.

1982. Blind justice: Police shootings in Memphis. Journal of Criminal Law and Criminology 73:702-22.

- 1987. Police shooting: Environment and license. In Controversial issues in crime and justice, edited by J. E. Scott and T. Hirschi. Newbury Park, CA: Sage.

. 1988. Police use of deadly force: Research and reform. Justice Quarterly 5:165-205.

Gain, C. 1971. Discharge of firearms policy: Effecting justice through administrative regulation. Unpublished memorandum, December 23.

Geller, W., and K. Karales. 1981. Split-second decisions: Shootings of and by Chicago police. Chicago: Chicago Law Enforcement Study Group.

Geller, W., and M. S. Scott. 1992. Deadly force: What we know. Washington, DC: Police Executive Research Forum.

It was a long and colorful career. 1991. The Philadelphia Inquirer, 16 July, 1-A.

Jacobs, D., and D. Britt. 1979. Inequality and police use of deadly force: An empirical assessment of a conflict hypothesis. Social Problems 26:403-12.

Kania, R. E., and W. C. Mackey. 1977. Police violence as a function of community characteristics. Criminology 15:27-48.

Liska, A. E., and J. Yu. 1992. Specifying and testing the threat hypothesis. In Social threat and social control, edited by A. Liska, 53-68. Albany: State University of New York Press.

Matulia, K. J. 1985. A balance of forces: Model deadly force policies and procedure. $2 \mathrm{~d}$ ed. Gaithersburg, MD: International Association of Chiefs of Police.

Sherman, L. W., and R. Langworthy. 1979. Measuring homicide by police officers. Journal of Criminal Law and Criminology 70:546-60.

Skolnick, J. H., and J. J. Fyfe. 1993. Above the law: Police and the excessive use of force. New York: Free Press.

Sorenson, J. R., J. W. Marquart, and D. E. Brock. 1993. Factors related to killings of felons by police officers: A test of the community violence and conflict hypotheses. Justice Quarterly 10 (3): 417-40.

Tennenbaum, A. N. 1994. The influence of the Garner decision on police use of deadly force. Journal of Criminal Law and Criminology 85:241-60.

United States Civil Rights Commission. 1979. Police practices and civil rights hearing held in Philadelphia, Pennsylvania, Volume 1, testimony. Washington, DC: Government Printing Office.

Waegel, W. B. 1984. The use of lethal force by police: The effect of statutory change. Crime \& Delinquency 30 (1): 121-40.

White, M. D. 1999. Police shootings in Philadelphia: An analysis of two decades of deadly force. Ph.D. diss., Temple University (Ann Arbor, MI: University Microfilms). 
2001. Controlling police decisions to use deadly force: Reexamining the importance of administrative policy. Crime \& Delinquency 47 (1): 131-51.

Michael D. White is an assistant professor of criminal justice at the University of North Florida. He received his Ph.D. in criminal justice from Temple University in 1999. His research interests include policing, particularly use of force by police, homicide, pretrial release and supervision, and drug treatment courts. 